\title{
Pengaruh Lingkungan Kerja Fisik Dan Non-Fisik Terhadap Kinerja Guru
}

\author{
Musafir Thahir \\ e-mail:ilyasthahir1309@gmail.com \\ (Dosen tetap Fakultas Agama Islam Universitas Muslim Indonesia Makassar)
}

\begin{abstract}
ABSTRSAK
Tujuan penelitian ini adalah untuk mengetahui dan menganalisis pengaruh kompetensi manajerial kepala madrasah, kompetensi guru, lingkungan kerja terhadap kinerja guru pada Madrasah Aliyah di Makassar. Penelitian ini dilaksanakan pada Madrasah Aliyah di Kota Makassar dengan jumlah populasi 530 orang guru dari 25 Madrasah Aliyah. Penetapan sampel menggunakan rumus slovin, yaitu 20 Madrasah Aliyah dan 84 orang responden. Analisis data yang digunakan adalah analisis deskriptif untuk menjelaskan data penelitian dan deskripsi penelitian, sedangkan untuk menganalisis data kuantitatif menggunakan alat analisis Regresi Linier Brganda. Hasil penelitian ini membuktikan bahwa secara simultan membuktikan hipotesis $\mathrm{H}_{0}$ ditolak dan $\mathrm{H}_{1}$ diterima, yaitu lingkungan kerja secara simultan berpengaruh terhadap kinerja guru Madrasah Aliyah di Makassar. Dan secara vartial, hipetesis $\mathrm{H}_{0}$ ditolak dan $\mathrm{H}_{1}$ diterima yaitu lingkungan kerja fisik dan lingkungan kerja non fisik keduanya berpengaruh secara positif dan signifikan terhadap kinerja guru Madrasah Aliyah di Makassar.
\end{abstract}

\section{Pendahuluan}

Dalam Undang-Undang Republik Indonesia No. 20 Tahun 2003 tentang Sistem Pendidikan Nasional (Bab II Pasal 3) dinyatakan bahwa:

Pendidikan nasional berfungsi mengembangkan kemampuan dan membentuk watak serta peradaban bangsa yang bermartabat dalam rangka mencerdaskan kehidupan bangsa, bertujuan untuk berkem-bangnya potensi peserta didik agar menjadi manusia yang beriman dan bertakwa kepada Tuhan Yang Maha Esa, berakhlak mulia, sehat, berilmu, cakap, kreatif, dan menjadi warga negara yang demokratis serta bertanggungjawab.

Dalam upaya mewujudkan fusngsi dan tujuan pendidikan tersebut, madrasah sebagai salah satu satuan pendidikan memiliki karakteristik yang berbeda dengan pendidikan umum. Karakteristik pendidikan Islam menurut Natsir yaitu: Pertama, pendidikan Islam adalah menekankan pada pencarian ilmu pengetahuan, penguasaan dan pengembangan atas dasar ibadah kepada Allah Swt. Setiap penganut Islam diwajibkan mencari ilmu pengetahuan untuk dipahami secara mendalam dalam taraf selanjutnya dikembangkan dalam kerangka ibadah guna kemaslahatan umat manusia. Kedua, pengakuan akan potensi dan kemampuan seseorang untuk berkembang dalam suatu kepribadian. Ketiga, pengamalan ilmu pengetahuan atas dasar tanggung jawab kepada Tuhan dan masyarakat manusia. Pengetahuan bukan hanya untuk diketahui, dan dikembangkan, melainkan sekaligus dipraktikkan dalam kehidupan nyata. (Natsir, 2017). 
Peningkatan mutu pendidik-an, banyak pakar sepakat bahwa yang paling menentukan adalah guru. Hampir semua usaha reformasi pendidikan, seperti pembaruan kuri-kulum dan penerapan metode mengajar baru, akhirnya bergantung kepada guru. Tanpa mereka tidak mungkin siswa menguasai bahan pelajaran dan strategi pembelajaran, tanpa mereka tidak mungkin dapat mendorong siswa untuk belajar secara sungguh-sungguh. Guna mencapai prestasi yang tinggi, maka segala upaya peningkatan mutu pendidikan tidak akan mencapai hasil maksimal tanpa guru (Adams dkk., dalam Natsir 2017).

Tugas guru erat kaitannya dengan peningkatan sumber daya manusia melalui sektor pendidikan, sehingga segala bentuk upaya perbaikan yang dilakukan untuk meningkatkan kualitas pendidikan tidak akan memberikan sumbangan yang signifikan tanpa di dukung oleh guru yang berkualitas. Namun de-mikian, peningkatan mutu guru akan dipengaruhi dengan banyak hal, salah satunya lingkungan kerja di mana guru melaksanakan tugas dan tanggung jawabnya sebagai pengajar dan pendidik. (Tilaar. 2000: 104). Baik buruknya kinerja seseorang dipengaruhi oleh banyak faktor, baik yang berasal dari dalam diri maupun dari luar dirinya. Demikian halnya dalam proses pembelajaran di madrasah sangat dipengaruhi ole faktor suasana, sarana dan fasilitas, sikap sumber daya manusia, dan faktor lingkungan lainnya (Wahjosu-midjo, 2013: 184).

Rumusan masalah dalam penelitian ini adalah apakah ling-kungan kerja fisik, lingkungan kerja non fisik berpengaruh secara positif dan signifikan terhadap kinerja guru pada Madrasah Aliyah di Makassar baik secara simultan maupun secara partial?

\section{Landasan Teori}

\section{A. Konsep Kinerja}

Kinerja yang baik merupakan salah satu sasaran organisasi dalam mencapai produktivitas kerja yang tinggi. Kinerja yang baik tidak terlepas dari kualitas sumber daya manusia yang baik pula. Kinerja merupakan aktivitas seseorang dalam melaksanakan tugas pokok yang diberikan kepadanya. Pelaksanaan tugas dan tanggung jawab tersebut merupakan perwujudan dari seluruh potensi dan kemampuan yang dimiliki seseorang (King,1993: 19). Selanjutnay, kinerja merupakan sebutan yang mengacu pada sikap mental dalam bentuk komitmen dari para anggota suatu profesi untuk senantiasa mewujudkan dan meningkatkan kualitas professional-nya (Surya, 2007: 14).

Kinerja didefinisikan sebagai hasil-hasil fungsi pekerjaan/kegiatan seseorang atau kelompok dalam suatu organisasi yang dipengaruhi oleh beberapa faktor untuk mencapai tujuan organisasi dalam periode waktu tertentu (Pabundu, 2006: 121). Karena itu, kinerja adalah hasil kerja secara kualitas dan kuantitas yang dicapai oleh seorang pegawai dalam melaksanakan tugasnya sesuai dengan tanggung jawab yang di-berikan kepadanya (Mangkunegara, 2009: 67). 
Pendapat yang hampir sama dikatakan bahwa kinerja adalah hasil kerja yang dicapai seorang dalam melaksanakan tugas-tugas yang diberikan kepadanya, berdasarkan kecakapan, pengalaman, kesungguh-an dan waktu. Selanjutnya, bahwa hasil kerja atau prestasi itu merupakan gabungan dari tiga faktor, yaitu terdiri dari (1) minat dalam bekerja, (2) penerimaan delegasi tugas, dan (3) peran dan tingkat motivasi seorang pekerja (Hasibuan, 2005: 64).

Dengan demikian, kinerja merupakan wujud prilaku atau hasil kerja yang dicapai oleh seseorang atau sekelompok orang dalam melaksanakan tugas sesuai dengan wewenang dan tanggung jawab yang dimiliki untuk mencapai tujuan organisasi. Karena itu, kinerja guru adalah kemampuan guru dalam mengelola kegiatan pembelajaran (Joni, 1991: 143).

Kinerja guru menurut Undang-Undang Republik Indonesia Nomor 14 tahun 2005 pasal 20 (a) tentang Guru dan Dosen adalah merencanakan pembelajaran, melak-sanakan proses pembelajaran yang bermutu, serta menilai dan meng-evaluasi hasil pembelajaran. Kinerja atau kemampuan guru dalam manajemen pembelajaran paling tidak meliputi: (a) kemampuan dalam menyusun program pembelajaran, (b) kemampuan dalam melaksanakan prosedur pembelajaran, dan (c) kemampuan dalam melaksanakan hubungan antar pribadi dengan peserta didik (Usman, 2004: 119).

Berdasarkan uraian-uraian tersebut di atas, dengan mengacu pada UndangUndang Republik Indonesia Nomor 14 tahun 2005 pasal 20 (a) maka dapat disimpulkan bahwa kinerja guru merupakan hasil usaha dan kemampuan seorang guru untuk membuat perencanaan peng-ajaran, melaksanakan kegiatan pembelajaran dan melakukan evaluasi hasil pembelajaran dengan baik.

\section{B. Konsep Lingkungan Kerja}

Lingkungan kerja adalah segala sesuatu yang ada di sekitar para pekerja yang dapat mem-pengaruhi dirinya dalam menjalankan tuags yang dibebankan kepadanya (Nitisemito, 1991: 184). Selanjutnya, Lingkungan kerja adalah kondisikondisi materil dan psikologis yang ada dalam perusahaan/tempat orang itu bekerja (Kartono, 1995: 160). Hal yang sama dikatakan oleh Anoraga dan Wijiyanti, bahwa lingkungan kerja adalah mencakup kondisi fisik dan non-fisik (psikologis) (Anoraga dkk, 1990: 57).

Untuk menciptakan ling-kungan kerja yang kondusif dan nyaman, sedikitnya diperlukan dua hal, yakni (1) guru itu sendiri (2) hubungan baik antara guru dengan orang tua/wali peserta didik dan masyarakat di sekitarnya (Mulyasa, 2003:1

Lingkungan kerja lebih dititikberatkan pada aspek fisik tempat kerja karena dengan tidak adanya gangguan dalam lingkungan bekerja maka guru akan dapat bekerja dengan baik, tetapi ling-kungan non fisik juga tidak harus diabaikan, karena ketersedian fasi-litas kerja tidak secara langsung dapat digunakan tanpa didukung ilmu dan keterampilan dalam hal pe-manfaatannya. Menurut Scott dalam Torang mendefinisikan lingkungan kerja fisik adalah semua bentuk ketergantungan hubungan yang dapat membuat organisasi bertahan hidup di sekitar sistem di mana 
dia berada (Ferina dalam Lestari, 2013). Hal yang sama dikatakan bahwa lingkungan fisik adalah semua keadaan berbentuk fisik yang terdapat di sekitar tampat kerja yang dapat mempengaruhi guru baik secara langsung maupun tidak langsung (Sedarmayanti, 2011: 26).

Selanjutnya, Sedarmayanti men-jelaskan bahwa lingkungan kerja fisik terdiri dari dua bagian, yaitu: (1) lingkungan kerja yang langsung berhubungan dengan pe-gawai (seperti: pusat kerja, kursi, meja, dan sebagainya), (2) ling-kungan kerja perantara, dapat juga disebut lingkungan kerja yang mempengaruhi kondisi manusia, misalnya: temperatur, kelembaban, sirkulasi udara, pencahayaan, kebisingan, warna dan lain-lain (Sedar-mayanti, 2011: 26). Dalam hal ini, ada beberapa faktor yang mem-pengaruhi lingkungan fisik, yaitu meliputi pencahayaan, pewarnaan, kebersihan, udara, kebisingan, dan keamanan (Barmawi dkk, 2014: 54).

Pencahayaan merupakan jum-lah penyinaran pada suatu bidang kerja yang diperlukan untuk melakukan kegiatan secara efektif. Pencahayaan di tempat kerja mem-bantu dalam memperlancar proses pekerjaan sehingga harus diupayakan pencahayaan yang baik di tempat kerja. pencahayaan memungkinkan guru dapat melihat objek-objek yang dikerjakan secara jelas, cepat, dan tepat (Barmawi dkk, 2014: 55).

Pemilihan warna ruangan kerja juga mempengaruhi kinerja guru. Warna dapat memberikan efek psikologis seseorang yang ada di sekitarnya. Pemberian warna tidak hanya pada tembok-tembok mad-rasah saja, tetapi peralatan madrjuga ah dapat diberi warna sesuai dengan keinginan (Barnawi, 2014: 56-57).

Lingkungan kerja yang bersih memberikan rasa nyaman bagi pegawai. Sebaliknya, tempat kerja yang kotor tidak akan nyaman dijadikan tempat untuk bekerja. Selanjutnya, kebisingan adalah ter-jadinya bunyi yang tidak dikehendaki sehingga mengganggu pekerjaan atau bahkan kesehatan . Demikian halnya dengan keamanan di tempat kerja akan menimbulkan ketenangan dalam bekerja. Ketenangan sangat dibutuh-kan pegawai untuk mengoptimalkan hasil kerja. Apabila keamanan pe-gawai tidak terjamin, maka timbullah kegelisahan dan kekhawatiran. Ke-gelisahan dan kekhawatiran akan berdampak buruk terhadap kinerja (Barnawi $\mathrm{dkk}, 2014:$ 62).

Dengan demikian, dapat di-simpulkan bahwa lingkungan fisik adalah segala sesuatu yang terdapat disekeliling guru yang dapat dilihat dan dirasakan kemudian memberikan efek samping baik negatif maupun positif terhadap kinerja guru.

Lingkungan non fisik adalah semua keadaan yang terjadi yang berkaitan dengan hubungan kerja, baik hubungan dengan atasan, maupun dengan sesama rekan kerja. Madrasah hendaknya dapat men-cerminkan kondisi yang mendukung kerja sama antar guru dengan atasan, maupun rekan kerja. Kondisi yang hendaknya diciptakan adalah suasana kekeluargaan, komunikasi yang baik, dan pengendalian diri (Sedarmayanti, 2011: 26).

Salah satu yang mempenga-ruhi kinerja guru adalah lingkungan kerja (Atik Novitasari dkk., 2012). Oleh karena itu, lingkungan kerja harus ditangani atau didesain agar menjadi kondusif terhadap pekerja untuk melaksanakan kegiatan dalam suasana yang aman dan nyaman (Zaenal dan Suharyo dalam Barnawi dan 
Arifin, 2014: 54). Dengan begitu, Lingkungan kerja dalam organisasi harus diperhatikan dan atur sedemikian rupa, sehingga dapat menciptakan suasana yang me-nyenangkan dan selanjutnya dapat mendorong semangat dalam bekerja dengan lebih giat, tetap terpelihara, tidak hanya kepada pegawai yang bersangkutan tetapi juga keseluruhan pegawai dalam organisasi tersebut.

Untuk menciptakan ling-kungan kerja yang kondusif dan nyaman, sedikitnya diperlukan dua hal, yakni (1) guru itu sendiri (2) hubungan baik antara guru dengan orang tua/wali peserta didik dan masyarakat di sekitarnya (Mulyasa, 2003:193).

Dari beberapa pendapat ter-sebut dapat disimpulkan bahwa, lingkungan kerja fisik dan non fisik yang kondusif akan mempengaruhi peningkatan produktivitas kinerja guru.

\section{Metode Penelitian}

Penelitian ini termasuk ke dalam penelitian korelasi dengan pendekatan kuantitatif, karena data yang digunakan adalah data yang berupa angka-angka dan pengo-laannya menggunakan analisis statistik. Penelitian ini bertujuan untuk mengetahui adakah hubungan yang positif dan signifikan antara lingkungan kerja dengan kinerja guru Madrasah Aliyah di Makassar. Dalam hal ini, penelitian korelasi adalah penelitian dengan tujuan untuk mengetahui hubungan antar variabel bebas dengan variabel terikat (Suharsimi Arikunto, 2005: 234).

Penelitian ini adalah penelitian lapangan, karena itu untuk memperoleh data yang dibutuhkan maka dilakukan melalui angket, wawancara, dan observasi. Populasi penelitian ini adalah seluruh guru Madrasah Aliyah di Makassar se-banyak 530 orang dari 3 Madrasah Aliyah Negeri dan 22 Madrasah Aliyah Swasta. Untuk menentukan jumlah sampel, peneliti meng-gunakan rumus Slovin. Berdasarkan perhitungan tersebut, maka jumlah responden sebanyak 84 orang sebagai perwakilan dari setiap Madrasah Aliyah di Makassar.

Instrumen yang digunakan pada penelitian ini adalah skala Likert. Dalam pengukuran setiap variabel, skala yang digunakan adalah model skala Likert. Jenis skala penilaian yang digunakan pada penelitian ini yaitu skala kategori. Skala kategori terdiri atas sejumlah kategori yang diatur dalam rangkaian yang urut. Penilaian memilih kategori yang paling tepat menunjukkan ciri tingkah laku orang yang sedang dinilai (Donald Ary, Jacobs dan Asghar Razavieh, 2007:274). Untuk keperluan analisis kuantitatif, maka jawaban diberi skor $1-4$.

Uji keabsahan data dilakukan melalui uji validitas dan uji reliabilitas. Uji validitas instrumen menggunakan product moment, pearson yang dibantu dengan menggunakan program SPSS versi 21.0. Selanjutnya, rumus yang digunakan dalam uji reliabilitas yaitu rumus Alpha, yang dibantu dengan menggunakan program SPSS versi 21.0. for Windows dengan uji keterandalan teknik Cronbach's alpha. Sedangkan metode pengo-lahan dan analisa data terbagi menjadi dua, yaitu analisis 
deskriptif presentase dan regresi linier berganda dengan menggunakan bantuan program SPSS versi 21.0. Analisis deskriptif presentase menggunakan skala yang telah ditentukan. Sedangkan analisis linier berganda meliputi uji persyaratan melalui uji normalitas dengan menggunakan rumus Kolmogrov-Smirnov dan liniertas data menggunakan uji F. Kemudian dilakukan uji asumsi klasik melalui uji multikolonieritas dengan melihat harga tolerance lebih besar 0.1 atau haerga VIF kurang 10, dan heterokedastisitas menggunakan uji Glejser. Sedangkan analisis selanjutnya dilakukan uji hipotesis dengan menggunakan uji simultan (uji F) dengan membandingkan probabilitas dengan taraf signifikansi (5\%), uji partial (uji t) dengan membandingkan probalitas dengan taraf signifikansi (5\%), koefisien determinasi simultan $\left(\mathrm{R}^{2}\right)$, dan kofieien determinasi $\left(\mathrm{r}^{2}\right)$.

\section{Hasil dan Pembahasan}

Analisis regresi bertujuan untuk melihat pengaruh variabel independen terhadap variabel de-penden, yakni melihat pengaruh variable lingkungan kerja fisik (X1) dan lingkungan kerja non fisik (X2). Hasil persamaan regresi untuk guru Madrasah Aliyah adalah sebagai berikut:

$$
\mathrm{Y}=11,652+0,383 \mathrm{X}_{1}+0,965 \mathrm{X}_{2}
$$

Persamaan regresi di atas terdapat nilai $\beta_{\mathrm{o}}$ atau nilai kostanta sebesar 11,652. Hal ini menunjukkan bahwa jika variabel independent seluruhnya dianggap 0, maka kinerja guru Madrasah Aliyah di Makassar (Y) adalah sebesar 11,652. Hal ini adalah indikasi dari pengaruh variabel lain yang tidak diteliti dalam pengaruh variabel independen ter-hadap kinerja guru Madrasah Aliyah di Makassar. Selain itu, persamaan regresi linier berganda di atas, terdapat nilai koefisien regresi variabel bebas $\mathrm{X}$ adalah positif, Nilai koefisien $\mathrm{X}$ yang positif artinya apabila terjadi perubahan pada variabel $X$, maka akan menyebabkan perubahan secara searah pada varia-bel Y.

Berdasarkan uraian diatas, persamaan regresi menunjukkan bahwa koefisien variabel independen yang membentuk model regresi untuk kinerja guru Madrasah Aliyah bernilai positif. Artinya semua variabel independen yang dimasuk-kan dalam model analisis dapat meningkatkan nilai kinerja guru Madrasah Aliyah di Makassar.

Analisis dari uji F-hitung ini dimaksudkan untuk menguji hipo-tesis penelitian, yaitu kompetensi manajerial kepala madrasah, kom-petensi guru, lingkungan kerja terhadap kinerja guru Madrasah Aliyah di Makassar.

Uji statistik F atau uji signifikansi simultan, pada dasarnya menunjukkan apakah semua variabel bebas yang dimasukkan dalam model mempunyai pengaruh secara ber-sama-sama terhadap variabel bebas Y. Uji F-hiting ini dilakukan dengan membandingkan $\mathrm{F}_{\text {hitung }}$ dengan nilai $\mathrm{F}_{\text {tabel }}$ pada taraf nyata $\alpha=0,0,5$. Uji F-hitung mempunyai pengaruh signifikan apabila $\mathrm{F}_{\text {hitung }}$ lebih besar dari $\mathrm{F}_{\text {tabel }}$ atau probabilitas kesalahan kurang dari 5\% $(\mathrm{P}<0,05)$.

Hasil analisis varians menun-jukkan bahwa nilai F-hitung yang diperoleh sebesar 23,059 dengan nilai signifikansi 99\%, artinya secara bersama-sama 


\section{variabel indepen-den signifikan mempengaruhi kinerja guru Madrasah Aliyah di Makassar.}

Selanjutnya hasil perhitungan regresi untuk nilai R (koefisien korelasi) untuk melihat pengaruh simultan dan nilai $\mathrm{R}^{2}$ (kofisien determinan) untuk melihat pengaruh atau hubungan variabel-variabel yang diteliti. Diketahui bahwa nilai kofisien korelasi (R / r-square) diperoleh sebesar 0,464. Artinya variabel independen yang terdiri atas lingkungan kerja fisik dan non-fisik memberikan pengaruh secara simul-tan terhadap variabel dependen kinerja guru, setelah dipresentasikan sebesar 46,40\%, selebihnya sekitar 53,60\% pengaruh variabel lain yang tidak dimasukkan dalam model analisis.

Uji t untuk menguji kemaknaan atau keberartian kofisien regresi partial. Pengujian melalui uji $t$ adalah dengan membandingkan $t_{\text {hitung }}$ dengan $t_{\text {tabel }}$ pada taraf nyata $\alpha=0.05$. Uji $\mathrm{t}$ berpengaruh signifikan apabila hasil perhutungan $\mathrm{t}_{\text {hitung }}$ lebih besar dari $t_{\text {tabel }}\left(t_{\text {hitung }}>\mathrm{t}_{\text {tabel }}\right)$ atau probobilitas kesalahan lebih kecil dari 5\% $(\mathrm{p}<$ 0.005).

Hasil analisis partial untuk mengetahui pengaruh masing-masing variabel independ lingkungan kerja fisik dan non-fisik terhadap variabel dependen pada Madrasah Aliyah di Makassar. Hasil analisis partial untuk variabel lingkungan kerja fisik Mad-rasah Aliyah diperoleh nilai t-hitung sebesar 3,056 dengan nilai signifikansi 0,003, artinya secara statistik variabel lingkungan fisik signifikan mempengaruhi kinerja guru Madra-sah Aliyah di Makassar. Namun demikian hasil analisis statistik menunjukkan bahwa nilai koefisien regresi untuk variabel lingkungan kerja fisik sebesar 0,383, artinya peningkatan lingkungan kerja fisik akan meningkatkan nilai kinerja guru madrasah sebesar nilai koefsien regresinya. Untuk itu kepala mad-rasah sebagai pimpinan dalam melakukan proses pembelajaran di madrasah perlu tetap memper-tahankan kinerja guru sebagai motor penggerak dalam kegiatan proses pembelajaran.

Hasil analisis partial untuk variabel lingkungan kerja non fisik pada Madrasah Aliyah di Makassar diperoleh nilai t-hitung sebesar 4,149 dengan nilai signifikansi 0,000 . Artinya secara statistik variabel lingkungan kerja signifikan mem-pengaruhi kinerja guru Madrasah Aliyah di Makassar. Namun demikian hasil analisis statistik menunjukkan bahwa nilai koefisien regresi untuk variabel lingkungan kerja non fisik sebesar 0,965, artinya peningkatan kualitas lingkungan kerja non fisik pada Madarasah Aliyah di Makassar akan mening-katkan nilai kinerja guru sebesar nilai koefsien regresinya. Untuk itu kepala madrasah sebagai pimpinan dalam melakukan proses pembelajaran di madrasah Aliyah perlu tetap memperbaiki lingkungan kerja non fisik agar kinerja guru dapat me-ningkat dalam melaksanakan proses pembelajaran.

Hasil analisis deskriptif untuk variabel lingkungan kerja non fisik pada Madrasah Aliyah di Makassar yaitu 90,48 \% menun-jukkan kinerja yang sedang, untuk itu kepala madrasah masih perlu me-lakukan startegi untuk meningkat-kan kondisi lingkungan kerja non fisik sebagai faktor penunjang dalam peningkatan proses pembelajaran pada Madrasah Aliyah di Makassar. 
Berdasarkan uraian tersebut, dan penelitian ini didukung oleh beberapa teori, di antaranya; Mulyasa (2003:193), Sedarmayanti (2011: 26), Barnawi dkk (2014: $54)$,

Menurut Mulyasa (2003:193), bahwa untuk menciptakan ling-kungan kerja yang kondusif dan nyaman, sedikitnya diperlukan dua hal, yakni (1) guru itu sendiri (2) hubungan baik antara guru dengan orang tua/wali peserta didik dan masyarakat di sekitarnya.

Menurut Sedarmayanti (2011: 26) menjelaskan bahwa lingkungan kerja fisik terdiri dari dua bagian, yaitu: (1) lingkungan kerja yang langsung berhubungan dengan pegawai (seperti: pusat kerja, kursi, meja, dan sebagainya), (2) ling-kungan kerja perantara, dapat juga disebut lingkungan kerja yang mem-pengaruhi kondisi manusia, misal-nya: temperatur, kelembaban, sirku-lasi udara, pencahayaan, kebisingan, warna dan lain-lain

. Menurut Barmawi dkk, 2014: 54 dan 62) bahwa ada bebe-rapa faktor yang mempengaruhi ling-kungan fisik, yaitu miputi pen-cahayaan, pewarnaan, kebersihan, udara, kebisingan, dan keamanan. Pencahayaan di tempat kerja membantu dalam memperlancar proses pekerjaan sehingga harus diupayakan pencahayaan yang baik di tempat kerja. pencahayaan memungkinkan guru dapat melihat objek-objek yang dikerjakan secara jelas, cepat, dan tepat. Lingkungan kerja yang bersih memberikan rasa nyaman bagi pegawai. Sebaliknya, tempat kerja yang kotor tidak akan nyaman dijadikan tempat untuk bekerja. Selanjutnya, kebisingan adalah ter-jadinya bunyi yang tidak dikehendaki sehingga mengganggu pekerjaan atau bahkan kesehatan. Demikian halnya dengan keamanan di tempat kerja akan menimbulkan ketenangan dalam bekerja. Ketenangan sangat dibutuh-kan pegawai untuk mengoptimalkan hasil kerja. Apabila keamanan pe-gawai tidak terjamin, maka timbullah kegelisahan dan kekhawatiran. Kege-lisahan dan kekhawatiran akan ber-dampak buruk terhadap kinerja.

Menurut Sedarmayanti (2011: 26) bahwa lingkungan non fisik adalah semua keadaan yang terjadi yang berkaitan dengan hubungan kerja, baik hubungan dengan atasan, maupun dengan sesama rekan kerja. Madrasah hendaknya dapat mencerminkan kondisi yang mendukung kerja sama antar guru dengan atasan, maupun rekan kerja. Kondisi yang hendaknya diciptakan adalah suasana kekeluargaan, komunikasi yang baik, dan pengendalian diri. (Sedarmaya-nti, 2011: 26).

Mulyasa (2003:193) Untuk menciptakan lingkungan kerja yang kondusif dan nyaman, sedikitnya diperlukan dua hal, yakni (1) guru itu sendiri (2) hubungan baik antara guru dengan orang tua/wali peserta didik dan masyarakat di sekitarnya.

Penelitian ini juga didukung oleh beberapa penelitian sebelumnya, di antaranya; (1) Peneltian disertasi yang dilakukan oleh Werang (2008/-2009) dengan judul "Hubungan Keterampilan Manajerial Kepala Sekolah, Status Sosial-Ekonomi Guru, Iklim Sekolah, dan Moral Kerja Guru dengan Kinerja Guru SMA Negeri di Kabupaten Merauke". Salah satu kesimpulan penelitian ini menyebutkan bahwa "ada hubungan langsung yang sig-nifikan antara keterampilan manaje-rial kepala sekolah, iklim sekolah dengan kinerja guru SMA Negeri di Kabupaten Merauke"; (2) Penelitian yang dilakukan oleh Novitasari dkk (2012) di SMA Kabupaten 
Kendal, dengan judul Pengaruh Kepemim-pinan Kepala Sekolah, Lingkungan Kerja Pendidikan, dan Pelatihan terhadap Kinerja Guru. Hasil penelitian tersebut menyebutkan, antara lain bahwa terdapat pengaruh kepemim-pinan kepala sekolah dan lingkungan kerja terhadap kinerja guru; (3) Penelitian Disertasi yang dilakukan oleh Sahrir (2016) dengan judul "Pengaruh Iklim Sekolah, Ke-puasan Kerja, dan Motivasi Ber-prestasi Terhadap Kinerja Guru SMA Negeri di Kabupaten Sidrap. Salah satu kesimpulan dari penelitian tersebut menyebutkan bahwa iklim sekolah berpengaruh secara tidak langsung melalui motivasi berprestasi teradap kinerja guru di SMA Negeri Kabupaten Sidrap.

\section{Kesimpulan}

Berdasarkan hasil penelitian yang telah diuraikan terdahulu, maka kesimpulan penelitian ini adalah sebagai berikut:

1. Secara simultan hasil penelitian ini membuktikan hipotesis $\mathrm{H}_{0}$ ditolak dan $\mathrm{H}_{1}$ diterima, yaitu bahwa lingkungan kerja fisik dan lingkungan kerja non fisik secara simultan berpengaruh positif dan signifikan terhadap kinerja guru Madrasah Aliyah di Makassar.

2. Secara partial, hasil penitian ini membuktikan bahwa hipotesis $\mathrm{H}_{0}$ ditolak dan $\mathrm{H}_{1}$ diertima, yaitu ling-kungan kerja fisik dan lingkungan kerja non fisik keduanya ber-pengaruh secara positif dan signifikan terhadap kinerja guru di Makassar.

\section{Daftar Pustaka}

Anoraga, Panji. 1990. Psikologi alam Perusahaan. Jakarta: Rineka Cipta.

Barnawi dan Mohammad Arifin. 2014. Kinerja Guru Profesional. Yogyakarta: AR-RUZZ MEDIA.

Hasibuan, Malaya S. P. 2005. Manajemen Sumber Daya Manusia. Jakarta: Bumi Aksara.

Joni, T.R. 1991. Kurikulum Inti Prog-ram Pendidikan Guru S1. Jakarta: LPTK.

King, Patria. 1993. Performance Planning and Apprasial. New York: Mcgraw-Hill Book Company.

Mangkunegara, Anwar Prabu. 2009. Manajemen Sumber Daya Manusia Perusahaan. Bandung: PT. Remaja Rosdakarya.

Mulyasa, Enco. 2003. Menjadi Kepela Sekolah Profesianal. Bandung: PT. Remaja Rosdakarya.

Natsir, Fatah, Nanat. 2007. Peningkatan Kualitas Guru dalam Perspektif Pendidikan Islam. Educationist (Online) Vol I No. 1, (http://file.upi.edu/Direktori/JURNAL/EDUCATIONIST, diakses 7 Mei 2017).

Nitisemito, S. Alex. 1991. Manajemen Personalia: Manajemen Sumber Daya Manusi. Jakarta: Ghalia Indonesia. 
Novitasari, Atik; Wahyudin, Agus; Setiyani, Rediana, 2012. Pengaruh Kepemimpinan Kepala Sekolah, Lingkungan Kerja, Pendidikan dan Pelatihan terhadap Kinerja Guru. Jurnal Economic Educa-tion Journal (2) Universitas Negeri Semarang, (Online) (http://-journal.-unnes.ac.id/sju/index.php/eeaj, diakses 5 September 2016).

Pabundu, M. Tika. 2006. Budaya Organisasi dan Peningkatan Kinerja Perusahaan. Jakarta: PT. Bumi Aksara.

Sedarmayanti. 2011. Tata Kerja dan Produktivitas Kerja. Bandung: Mandar Maju.

Tilaar, H.A.R. 2000. Paradigma Baru Pendidikan Nasional. Jakarata: Rineka Cipta.

Usman, Uzer. 2004. Menjadi Guru Profesional. Bandung: PT. Remaja Rodyakarya.

Wahjosumidjo. 2002. Kepemimpinan Kepala Sekolah Tinjauan Teoritik dan Permasalahannya. Jakarta: Raja Grafindo Persada.

Werang, Baslitus Reda, 2008/2009 (Disertasi). Hubungan Kete-rampilan Managerial Kepala Sekolah, Status Sosial-Ekonomi Guru, Iklim Sekolah, dan Moral Kerja Guru dengan Kinerja Guru SMA Negeri di Kabupaten Merauke (Online), (http://pasca.um.ac.id/abstrak/-disertasi-s3 diakses 4 agustus 2016). 